\title{
LAND-USE CHANGES AT NEST SITES OF THE LITTLE OWL (ATHENE NOCTUA) IN THE SOUTH-MORAVIAN REGION OF THE CZECH REPUBLIC
}

\author{
KAREL POPRACH ${ }^{1}$, LIBOR OPLUŠTIL $^{2}$, FRANTIŠEK KRAUSE $^{3}$ \\ AND IVO MACHAR ${ }^{4 *}$ \\ ${ }^{1,4}$ Department of Development and Environmental Studies, Faculty of Science, Palacky \\ University, Olomouc, tř. 17. listopadu 12, 77140 Olomouc; e-mail: karel.poprach@tyto.cz \\ ${ }^{2}$ Podolí 286, 66403 Podolí u Brna; e-mail: libor.oplustil@email.cz \\ ${ }^{3}$ Břetislavova 8,69002 Břeclav; email: bretislavovafk@seznam.cz \\ * Corresponding author e-mail: ivo.machar@upol.cz
}

Received: $5^{\text {th }}$ April 2017, Accepted: $15^{\text {th }}$ June 2017

\begin{abstract}
The Little Owl is currently endangered bird species of agricultural lowland areas in Central Europe. Nesting sites of the Little Owl are often old trees as well as buildings and quarries with suitable nesting cavities. The Little Owl has severely declined in a major part of Europe during the past decades. Information on habitat requirements of the Little Owl and data related to land-use changes at nest sites (covering both the breeding and foraging habitats) are needed for conservation programmes aimed at this bird species. Land-use changes in farmland rank among frequently discussed negative factors causing the population decline of the Little Owl. The aim of this study is to analyse land-use changes at nest sites of the Little Owl in the South-Moravian region (Czech Republic) between the years 1976/1977 and 2014 . In both studied periods (1976/1977 and 2014), the most important land-use type within $500 \mathrm{~m}$ from the nest sites of the Little Owl was arable land $(66.94 \%-62.25 \%)$, followed by built-up areas $(19.97 \%-22.41 \%)$, while the other land-use types made up less than $5 \%$. The proportion of the particular land-use type did not change significantly between the years 1976/1977 and 2014. The most important change in comparison with the period 1976/1977 was the decrease in the area of arable land by $4.69 \%$ and that of orchards and gardens by $1.99 \%$, while the surface of built-up areas increased slightly by $2.45 \%$ and that of meadows and pastures by $1.5 \%$. The analysis shows that at the known nest sites of the Little Owl in the South-Moravian region (Czech Republic), there were no significant changes in the proportion of the particular land-use types within $500 \mathrm{~m}$ from the nests between the years 1976/1977 and 2014. Based on these results, we can conclude that in comparison with the availability of nest sites, which seems to be the important limiting factor for the occurrence and population density of the Little Owl, land-use changes in study area were not very important factor influencing decline of the Little Owl.
\end{abstract}

Keywords: Agricultural land, birds, GIS analyse, land-cover, nest site. 
Poprach K., Opluštil L., Krause F., Machar I.: Land-use changes at nest sites of the Little Owl (Athene noctua) in the South-Moravian region of the Czech Republic

\section{INTRODUCTION}

The Little Owl (Athene noctua) is a Turcmenic-Mediterranean faunal element (Vogus, 1962) which uses open habitats such as meadows, grasslands and fields as hunting grounds. Nesting takes place in tree cavities which are also important as raised stands (Framis et al., 2011). In Central Europe, open agricultural land is a typical hunting habitat of the Little Owl (Scherzinger, 1981). Nesting sites are often old trees as well as buildings and quarries with suitable cavities (Mebs \& Scherzinger, 2000). The Little Owl has severely declined in a major part of Europe during the past decades (Šálek \& Schröpfer, 2008; Zmihorski et al., 2009). This population trend of the Little Owl is similar as population trends of other owls breeding in agricultural landscapes in Europe. Artificial nest boxes seem to be a simple and effective conservation measure supporting the population restoration of the Little Owl. However, further information on habitat requirements of the Little Owl and data related to land-use changes at nest sites (covering both the breeding and foraging habitats) are needed for conservation programmes aimed at this endangered bird species.

Several decades ago, the Little Owl was one of the most common breeding owl species in the Czech Republic. It was widespread in lowland areas of the country, breeding in almost every settlement there, and its population comprised several thousands of breeding pairs. Since the 1960s the species started to decline gradually (Hudec, 1983) and the decrease became more pronounced in the late $20^{\text {th }}$ century (Hudec \& Št'astný, 2005). The breeding population of the Little Owl in the Czech Republic in the year 1990 was estimated at 600700 pairs (Danko et al., 1994). On the other hand, Schröpfer (1996) mentioned 1,000-2,100 pairs for the period 1993-1995, and the same author (Schröpfer, 2000) noted 500-1,000 pairs for the period 1998-1999. According to the results of monitoring of the Little Owl in the Czech Republic, the breeding population did not exceed 100 pairs in the year 2015 and it was approximately 130 pairs in 2016 (Opluštil, 2016).

The causes of the dramatic decline in numbers of the Little Owl in the Czech Republic are not quite clear. Some authors (Hudec et al., 2005) suggest climatic factors to influence the Little Owl population (severe winter rich in snow). However, in lowland areas of Central Europe, such winters have been rather exceptional in recent decades. Other potential important causes of the population decrease of the Little Owl mentioned in the literature include road an railway casualties (Hernandez, 1988; Bauer \& Berthold, 1996) and mortality due to technical dangers, such as concrete electric poles with a vertical inner cavity where the Little Owls hide but are not able to leave, or molasses tanks in agricultural farms where the Little Owls get drowned (Machar \& Poprach, 2012).

The main causes of the dramatic decline in numbers of the Little Owl mentioned in the literature include intensification of agriculture (use of chemicals and rodenticides), increased predation pressure due to high abundance of small carnivores, loss of breeding opportunities related to the elimination of scattered vegetation in the landscape, or climatic factors (Št'astný et al., 1987; Martiško, 1994).

Land-use changes in farmland rank are one of important factors among frequently discussed negative factors causing the population decline of the Little Owl (e.g. Cramp, 1985; Génot et al., 1997; Šálek \& Berec, 2001; Machar, 2012). As pointed out by Kitowski \& Stasiak (2013), different types of grassland with high availability of potential prey are the most important feeding habitat within the Little Owl territories in the Central European farmland. The reduction of the area covered by grasslands is recognized as an important factor in the disappearance of the occurrence sites of the Little Owl (Loske, 1986; Finck, 1990). The study by Kitowski \& Pawlega (2009) revealed that insects associated with pastures as well as with stored grain is a significant component of the Little Owl diet. 
Decreasing numbers of cattle in the farms result in deterioration of the conditions of pastures as hunting areas for the Little Owl. This deterioration refers to factors such as the increase of grass length, due to lower pressure in the form of grazing, which may limit the access to potential prey, or to the lack of dung pats, which attract various species of insects (Denholm-Young, 1978).

Presented study deals with land-use changes in the South-Moravian region (Czech Republic) in the context of changes in abundance of breeding population of the Little Owl. This region has been chosen as the typical landscape with convenient environmental conditions for the Little Owl in Europe based on current knowledge of this species. In the South-Moravian region (the area of the current South-Moravian region together with the districts of Jihlava, Kroměříž, Prostějov, Třebíč, Uherské Hradiště, Zlín and Žd'ár nad Sázavou), the Little Owl was a regularly and commonly breeding species in the first half of the $20^{\text {th }}$ century, mainly at the altitudes below $450 \mathrm{~m}$ a.s.1. At higher elevations (up to $550 \mathrm{~m}$ a.s.1.) it was rare or absent. Already after the year 1940, a decline in numbers was recorded, this became more pronounced after 1957. The aim of this study is to analyse land-use changes at nest sites of the Little Owl in the South-Moravian region between the years 1976/1977 and 2014.

\section{MATERIAL AND METHODS}

We analysed the available data on breeding of the Little Owl in the South-Moravian region $\left(1620 \mathrm{~km}^{2}\right)$ from the period $1998-2014$. These data are related to altogether 35 nest sites of the Little Owl (Fig. 1). The nest site is defined as a concrete nesting place of the Little Owl; there may be more than one nest site in a settlement (nesting of two pairs). Primary data were processed using the TYTO database application (Poprach, 2011). Within $500 \mathrm{~m}$ from each nest site (flying range of the Little Owl during foraging, usually less than 200-300 $\mathrm{m}$ from the nest), individual land-use types were recorded from the orthophotomaps coming from the years 1976/1977 and 2014. For each site and aerial image, the following land-use types were distinguished: 1) woodland; 2) meadows and pastures; 3) arable land; 4) hedgerows, windbreaks and parks; 5) orchards and gardens; 6) vineyards; 7) water bodies; 8) built-up area. The area of the individual land-use type was measured using GIS application of Esri products (Arc-Info v.9) and the results for the particular nest site and aerial images from the years 1976/1977 and 2014 were compared.

Fig. 1: Distribution of the studied breeding sites of the Little Owl (Athene noctua) in the South-Moravian region (Czech Republic) in the period 1998-2014

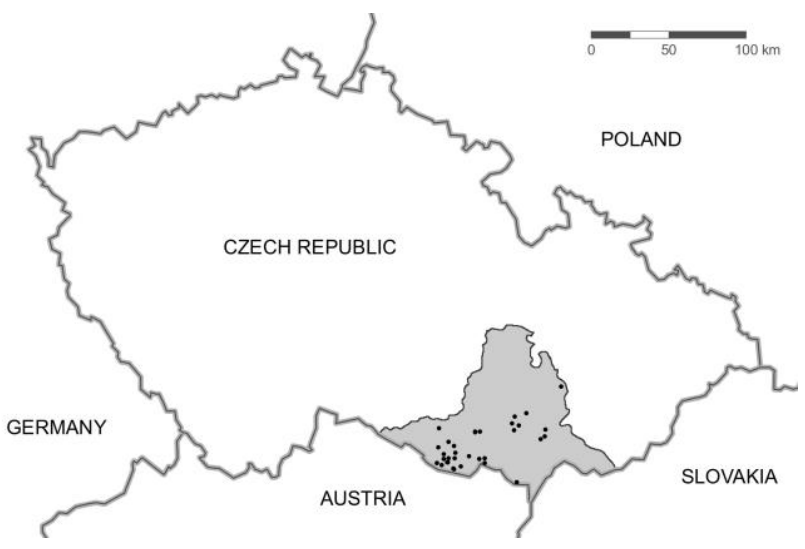


Poprach K., Opluštil L., Krause F., Machar I.: Land-use changes at nest sites of the Little Owl (Athene noctua) in the South-Moravian region of the Czech Republic

\section{RESULTS}

In the period 1998-2014, we localised altogether 35 nest sites of the Little Owl in the South-Moravian region. Of them, 33 were situated in farms, 1 in an attic of a castle and 1 in a dwelling house. Altogether 15 nest sites were „natural“ (Little Owls used the existing nesting opportunities) and 20 sites were in nest boxes (designed for the Little Owl or the Barn Owl, respectively) installed in farming facilities. In the study period, we recorded altogether 69 nesting attempts at the 35 nest sites. At most of the sites, breeding occurred for 1-3 years, however, continuous nesting of the Little Owl at the same site for six years was recorded at two nest sites in the Břeclav district. In a large part of the nest sites $(51 \%, \mathrm{n}=18)$, we registered nesting in one year only. In the recent period 2012-2014, nesting of the Little Owl was recorded at 8 nest sites ( $23 \%$ of the 35 nest sites). The decline in the nesting sites has been caused by reduced density in mostly the same area (Fig. 1.).

In both studied periods (1976/1977 and 2014), the most abundant land-use type found within $500 \mathrm{~m}$ from the nest sites of the Little Owl was arable land $(66.94 \%-62.25 \%)$, followed by built-up areas (19.97-22.41\%), while the other land-use types made up less than $5 \%$. The proportion of the particular land-use type did not change significantly between the years 1976/1977 and 2014 (Tables 1-2). The most important change in comparison with the period $1976 / 1977$ is the decrease in the area of arable land by $4.69 \%$ and that of orchards and gardens by $1.99 \%$, while the surface of built-up areas increased slightly by $2.45 \%$ and that of meadows and pastures by $1.5 \%$.

\section{DiSCUSSION AND CONCLUSION}

During the mapping of breeding distribution of birds in the Czech Republic in the period 1973-1977, the occurrence of the Little Owl in the breeding season was recorded in $72 \%$ of the mapping squares $(n=607)$ and breeding of the species was confirmed in $39 \%$ of the squares $(\mathrm{n}=331)$ (Št'astný et al., 1987). During the subsequent mapping in the period 19851989, the occurrence of the Little Owl in the breeding season was reported from $68 \%$ of the squares $(\mathrm{n}=428)$ and confirmed breeding from $30 \%$ of the squares $(\mathrm{n}=189)$ (Št'astný et al., 1996). The breeding distribution of the Little Owl thus did not change much between the two atlas mapping periods. A sharp decline in numbers of the Little Owl in the Czech Republic is apparent first from the results of bird mapping in the period 2001-2003, when the occurrence of the species in the breeding season was recorded in $27 \%$ of the squares only $(n=168)$ and confirmed breeding in $6 \%$ of the squares (Št'astný et al., 2006). This population decline has continued until today (Šálek, 2014). The question arises whether there indeed was a $50 \%$ decline of the Little Owl population between the periods 1993-1995 and 1998-1999 (e.g. due to the severe winter of 1995/1996) or whether the data on numbers for the period 19931995 were overestimated. The estimate of the number of pairs was based on mean population densities of the Little Owl: 0.33 and 0.17 pairs $/ 10 \mathrm{~km}^{2}$, respectively, in the years 1993-1995, and 0.12 pairs $/ 10 \mathrm{~km}^{2}$ in the period 1998-1999. The values of mean densities were extrapolated to the whole area of the Czech Republic $\left(78,870 \mathrm{~km}^{2}\right)$, i.e. including areas not inhabited by, and unsuitable for, the Little Owl, such as mountainous areas and forest complexes. As a certain compensation of the estimate and possible overestimation, the in the period 1998-1999 the monitoring methods were not observed strictly in some areas and the local populations of the Little Owl thus could have been underestimated.

During the first mapping of birds of the Czech Republic in 1973-1977, the breeding distribution of the Little Owl in the South-Moravian region was still more or less the same, 
but a marked decline in numbers was apparent. In the early 1980s, the Little Owl was still quite abundant in some areas, e.g. in the Břeclav district (mapping square no. 7267) there were 6-7 breeding pairs. After the year 1985, a further population decrease and disappearance of the species from a number of sites, regularly occupied as late as in the early 1980s, was recorded. In the early 1990s, the breeding population in the region was estimated at less than 50 pairs (Martiško, 1994). Danko et al. (1994) estimated the population size in the then South-Moravian region at 30 breeding pairs by the year 1990, which was probably an undervalued estimate.

The Little Owl prefers sheltered roost sites such as tree cavities with multiple entrances. This important habitat is often negatively affected by human activities in the landscape (Bock et al., 2013). In some areas, where Little Owls nest in tree holes, a factor reducing their population could be felling of old trees (Génot et al., 1997). However, in Central Europe, this factor plays a rather insignificant role due to the decreasing importance of tree holes as nesting sites, both in agricultural landscape and in towns (Kitowski \& Grzywaczewski, 2010).

In eastern Poland, Kitowski \& Stasiak (2013) showed that the disappearance of nest sites of the Little Owl is caused by factors connected with the changes in farming practices, especially demolitions of buildings motivated by tax burdens, abandonment of pig and cattle production, including pasturing in the vicinity of farm buildings and increase in the area of rapeseed fields in farms.

Habel et al. (2015) analysed the effects of land-use changes on the Little Owl in 20012010 across Western Luxembourg. They found out a large-scale transformation of pastures with single trees into arable land during the past 10 years. Despite this agricultural intensification, the presence of the Little Owl increased, most likely as a result of the installation of nest boxes. Their results indicate that land-use parameters such as the presence of arable land, forests, pastures and pastures with trees had only a negligible impact on the occurrence of the Little Owl.

The results of our study indicate a similar interpretation. The analysis shows that at the known nest sites of the Little Owl in the South-Moravian region (Czech Republic), there were no significant changes in the proportion of the particular land-use types within $500 \mathrm{~m}$ from the nests between the years 1976/1977 and 2014. We believe the composition of the land-uses within $500 \mathrm{~m}$ of the total landscape is sufficiently representative based on the knowledge of maximum size of foraging range of the Little Owl. However, the proportion of the particular land-use types is not directly connected with the farming practices applied at these sites. Even though the proportion of crops is similar in both studied periods, the Little Owl may react e.g. on the way and frequency of mowing of meadows and pastures, loss of food due to the use of chemicals in agriculture, increased predation pressure as well as the other above mentioned negative factors.

We can conclude that in comparison with the availability of nest sites, which seems to be the limiting factor for the occurrence and population density of the Little Owl, land-use parameters play a rather negligible role. This conclusion is in line with other studies focussing on the habitat requirements of the Little Owl, indicating a positive correlation with open land (Dalbeck et al., 1999; Kasprzykowski \& Golawski, 2006; Loske, 2007) and the presence of pastures (Mebs \& Scherzinger, 2000). The high relevance of open land might be connected with the hunting behaviour of the Little Owl - the bird typically feeds where crops have been recently harvested or replanted or where meadows have been cut (Tomé et al., 2011). These conditions simplify visual recognition of prey and hunting (Schönn et al., 1991). In contrast to meadows and pastures, arable land is only suitable as long as the crop is still short, but becomes unsuitable if high standing crops make visual recognition of prey 
Poprach K., Opluštil L., Krause F., Machar I.: Land-use changes at nest sites of the Little Owl (Athene noctua) in the South-Moravian region of the Czech Republic

difficult (van Nieuwenhuyse et al., 2008). This explanation is further supported by the negative correlation between the increase of arable land and the population density of the Little Owl recorded in some areas in Europe.

\section{ACKNOWLEDGEMENTS}

We thank anonymous reviewers for valuable comments on the manuscript. We are also grateful to V. Škorpíková, A. Reiter \& Z. Tunka for providing us with data on three nest sites of the Little Owl in the South-Moravian region. The analyses of land-use changes were financially supported by the Department of Environment of the South-Moravian Regional Authority. Publication of the results of the analysis was supported by the grant „Cultural landscape of the Olomouc Arcidiocese - research, presentation and management" within the NAKI II programme financed from the state budget of the Czech Republic. We thank Eva Cepáková for translation into English.

\section{REFERENCES}

Bauer, H. G. \& Berthold, P. (1996). Die Brutvögel Mitteleuropas. Bestand und Gefährdung. Wiesbaden: AULA Verlag.

Bock, A., Naef-Daenzer, B., Keil, H., Korner-Nievergelt, F., Perrig, M. \& Grüebler, M. U., (2013). Roost site selection by Little Owl Athene noctua in relation to environmental conditions and life-history stages. Ibis 155: 847-856.

Cramp, S., (1985). Handbook of the Birds of Europe, the Middle East and North Africa. Volume IV - Terns to Woodpeckers. Oxford University Press, Oxford, New York.

Dalbeck, L., Bergerhausen, W. \& Hachtel, M., (1999). Habitatpräfenzen des Steinkauzes (Athene noctua) im ortsnahen Grunland. Eulen-Rundblick 48 (49): 3-15.

Danko, Š., Diviš, T., Dvorská, J., Dvorský, M., Chavko, J., Karaska, D., Kloubec, B., Kurka, P., Matušík, H., Peške, L., Schröpfer, L. \& Vacík, R., (1994). Stav poznatkov o početnosti hniezdnych populácií dravcov (Falconiformes) a sov (Strigiformes) v Českej a Slovenskej republike k roku 1990 a ich populačný trend v rokoch 1970-1990. Buteo 6: 1-89.

Denholm-Young, P. A., (1978). Studies of decomposing cattle dung and its associated fauna. Ph.D. Thesis. University of Oxford.

Finck, P., (1990). Seasonal variation of territory size with Little Owl Athene noctua. Oecologia 83 (1): 68-75.

Framis, H., Holroyd, G. L. \& Manosa, S., (2011). Home range and habitat use of the Little Owl Athene noctua in an agricultural landscape in coastal Catalonia. Animal Biodiversity Conservation 34: 369-378.

Génot, J. C., Juilard, M. \& van Nieuwenhuyse, D., (1997). Little Owl Athene noctua. In: Hagemeijer E.J.M., Blair M.J. (eds.): The EBCC Atlas of European Breeding Birds: Their Distribution and Abundance (pp. 408-409). T. \& A. D. Poyser, London.

Habel, J. C., Braun, J., Fischer, Ch., Weisser, W. W. \& Gossner, M. M., (2015). Population restoration of the nocturnal bird Athene noctua in Western Europe: an example of evidence based species conservation. Biodiversity Conservation 24: 1743-1753.

Hernandez, M., (1988). Road mortality of the Little Owl Athene noctua in Spain. Journal of Raptor Research 22 (3): 81-84. 
Hudec, K., (1983). Fauna ČSSR. Ptáci 3/I. Academia, Praha.

Hudec, K. \& Št’astný, K., eds., (2005). Fauna $\check{C} R$. Ptáci 2/II. Academia, Praha.

Kasprzykowski, Z. \& Golawski, A., (2006). Habitat use of the Barn Owl Tyto alba and Little Owl Athene noctua in Central-Eastern Poland. Biology Letters 43: 33-39.

Kitowski, I. \& Grzywaczewski, G., (2010). Occurence of the Little Owl Athene noctua in town and cities of Poland. In: Barančoková, M., Krajčí, J., Kollár, J., Belčáková, I. (eds): Landscape ekology - Methods, applications an interdisciplinary approach (pp. 791-801). Bratislava, ILE, Slovak Academy of Science.

Kitowski, I. \& Pawlega, K., (2010). Food Composition of the Little Owl Athene noctua in Farmald Areas of South East Poland. Belgian Journal of Zoology 140 (2): 203-211.

Kitowski, I. \& Stasiak, K., (2013). The disapereance of barn Owl Tyto alba and Little Owl Athene noctua occurence sites in farmland in East Poland. Ekológia (Bratislava) 32 (4): 361368.

Loske, K. H., (1986). Zum Habitat des Steinkauzes (Athene noctua) in der Bundesrepublik Deutschland. Vogelwelt 107 (3): 91-101.

Loske, K. H., (2007). Erfassung des Steinkauzes (Athene noctua) in Krefeld: Ein Beispiel für die Berücksichtigung geschützter Arten in der Bauleitplanung. Natur in NRW 3: 2-8.

Machar, I., (2012). Changes in Ecological Stability and Biodiversity in a Floodplain Landscape. In: Applying landscape ecology in conservation and management of the floodplain forests (Czech Republic) (pp. 73-87). Olomouc: Palacky University. ISBN 978-80-244-2997-7.

Machar, I. \& Poprach, K., (2012). Tanks and Cisterns for Fodder Molasses on Farms as Ecological Traps. Listy cukrovarnické a řepařské 128 (11): 347-349.

Martiško, J., ed., (1994). Hnizdní rozšířeni ptáků - Jihomoravský region. Část I. Nepěvci. Moravské zemské muzeum \& ČSOP ZO Pálava, Brno.

Mebs, T. \& Scherzinger, W., (2000). Die Eulen Europas: Biologie, Kennzeichen. Bestände. Franckh-Kosmos Verlags-Gmbh \& Co., Stuttgart.

Opluštil, L., (2016). Sýček obecný (Athene noctua). Zpravodaj SOVDS 16: 34-35.

Opluštil, L., (2017). Sýček obecný (Athene noctua). Zpravodaj SOVDS 17: 33-34.

Poprach, K., (2011). Prezentace databáze občanského sdružení TYTO. In.: Sedláček, O., Hošková, L., Škorpilová, J. (eds.) 2011: "Ornitologie věda pro každého", celostátni konference České společnosti ornitologické (pp. 1-20), Mikulov. Sborník z abstraktů z konference 7. až 9. ř́ijna 2011. ČSO, Praha.

Poprach, K. (2015). Monitoring stavu před realizací projektu „, Ochrana a podpora hnízdní populace sýčka obecného a sovy pálené v Ústeckém kraji s lokální pusobností projektu v jiných regionech České republiky". TYTO, z. s., Nenakonice.

Scherzinger, W. (1981). Vorkommen und Gefährdung der vier kleinen Eulenarten in Mitteleuropa. Ökologie der Vögel 3: 283-292.

Schönn, S., Scherzinger, W., Exo, K. M. \& Ille, R., (1991). Der Steinkauz. Urania Verlagsgesellschaft mbH, Leipzig.

Schröpfer, L., (1996). Sýček obecný (Athene noctua) v České republice - početnost a rozšíření v letech 1993-1995. Buteo 8: 23-38.

Schröpfer, L., (2000). Sýček obecný (Athene noctua) v České republice - početnost a rozšíření v letech 1998-1999. Buteo 11: 161-174. 
Šálek, M., (2014). Dlouhodobý pokles početnosti sýčka obecného (Athene noctua) v jádrové oblasti jeho rozšíření v Čechách. Sylvia 50: 2-11.

Šálek, M. \& Berec, M., (2001). Rozšíření a biotopové preference sýčka obecného (Athene noctua) ve vybraných oblastech jižních Čech. Buteo 12: 127-134.

Š́lek, M. \& Schröpfer, L., (2008). Population decline of the Little Owl Athene noctua in the Czech Republic. Polish Journal of Ecology 56 (3): 527-534.

Št’astný, K., Bejček, V. \& Hudec, K., (1996). Atlas hnízdního rozšiřrení ptáků v České republice 1985-1989. Nakladatelství a vydavatelství H \& H, Jinočany.

Št’astný, K., Bejček, V. \& Hudec, K., (2006). Atlas hnízdního rozšiření ptáků v České republice. Aventinum, Praha.

Št’astný, K., Randík, A. \& Hudec, K. (1987). Atlas hnízdního rozšǐrení ptáků v ČSSR 1973/77. Academia, Praha.

Tomé, R., Dias, M. P., Chumbinho, A. C. \& Bloise, C. (2011). Influence of perch height and vegetation structure on the foraging behaviour of Little Owl Athene noctua: How to achieve the same success in two distinct habitats. Ardea 99: 17-26.

Van Nieuwenhuyse, D., Génot, J. C. \& Johnson, D. H. (2008). The Little Owl Conservation, ekology and behaviour of Athene noctua. Cambridge: Cambridge University Press.

Vogus, K. H., (1962). Die Vogelwelt Europas und ihre Verbreitung. Hamburg, Berlin.

Zmihorski, M., Romanowski, J. \& Osojaca, G. (2009). Habitat preferences of a declining population of the Little Owl Athene noctua in Central Poland. Folia Zoologica 58: 207-215. 


\section{APPENDIX}

Table 1: Absolute area of the particular land-use types within $500 \mathrm{~m}$ from the nest sites of the Little Owl (Athene noctua) in the South-Moravian region, Czech Republic, in the years 1976/1977 and $2014(n=35)$

\begin{tabular}{|c|c|c|c|c|}
\hline $\begin{array}{l}\text { Number of } \\
\text { the nest in } \\
\text { TYTO } \\
\text { database }\end{array}$ & Land-use type & $\begin{array}{l}\text { Orthophoto } \\
\text { 1976/1977 (m2) }\end{array}$ & $\begin{array}{l}\text { Orthophoto } \\
2014(\mathrm{~m} 2)\end{array}$ & \begin{tabular}{|lr} 
Land-use resanges \\
between 1976/1977 \\
and $2014(\mathrm{~m} 2)$
\end{tabular} \\
\hline \multirow[t]{5}{*}{582} & meadows and pastures & 0 & 34328,8 & $-34328,8$ \\
\hline & arable land & 651278,1 & 620556,6 & 30721,5 \\
\hline & hedgerows, windbreaks and parks & 4794,889 & 10330,23 & $-5535,341$ \\
\hline & built-up areas & 129325,6 & 120182,5 & 9143,1 \\
\hline & $\sum$ & 785398,589 & 785398,13 & 0,459 \\
\hline \multirow[t]{6}{*}{253} & meadows and pastures & 6236,776 & 21334,95 & $-15098,174$ \\
\hline & arable land & 609397,2 & 587828,1 & 21569,1 \\
\hline & hedgerows, windbreaks and parks & 9232,36 & 26123,32 & $-16890,96$ \\
\hline & orchards and gardens & 18340,99 & 11285,01 & 7055,98 \\
\hline & built-up areas & 142190,8 & 138826,9 & 3363,9 \\
\hline & $\sum$ & 785398,126 & 785398,28 & $-0,154$ \\
\hline \multirow[t]{6}{*}{583} & meadows and pastures & 20839,52 & 18723,92 & 2115,6 \\
\hline & arable land & 616279,4 & 582018 & 34261,4 \\
\hline & hedgerows, windbreaks and parks & 14036,87 & 17503,58 & $-3466,71$ \\
\hline & orchards and gardens & 32270,95 & 13466,33 & 18804,62 \\
\hline & built-up areas & 101971,5 & 153686,3 & $-51714,8$ \\
\hline & $\sum$ & 785398,24 & 785398,13 & 0,11 \\
\hline \multirow[t]{5}{*}{584} & arable land & 582484,6 & 697969,2 & $-115484,6$ \\
\hline & hedgerows, windbreaks and parks & 21054,32 & 23154,53 & $-2100,21$ \\
\hline & orchards and gardens & 146659,2 & 25464,07 & 121195,13 \\
\hline & built-up areas & 35200,05 & 38810,26 & $-3610,21$ \\
\hline & $\sum$ & 785398,17 & 785398,06 & 0,11 \\
\hline \multirow[t]{3}{*}{585} & meadows and pastures & 0 & 2848,659 & $-2848,659$ \\
\hline & arable land & 666945,7 & 668378,5 & $-1432,8$ \\
\hline & hedgerows, windbreaks and parks & 42058,18 & 12691,59 & 29366,59 \\
\hline
\end{tabular}


Poprach K., Opluštil L., Krause F., Machar I.: Land-use changes at nest sites of the Little Owl (Athene noctua) in the South-Moravian region of the Czech Republic

\begin{tabular}{|c|c|c|c|c|}
\hline & orchards and gardens & 0 & 31592,26 & $-31592,26$ \\
\hline & water bodies & 3853,707 & 6259,45 & $-2405,743$ \\
\hline & built-up areas & 72540,61 & 63627,96 & 8912,65 \\
\hline & $\sum$ & 785398,197 & 785398,419 & $-0,222$ \\
\hline \multirow[t]{6}{*}{574} & woodland & 59372,02 & 78636,58 & $-19264,56$ \\
\hline & meadows and pastures & 20009,8 & 31426,53 & $-11416,73$ \\
\hline & arable land & 578353,6 & 347723,6 & 230630 \\
\hline & vineyards & 4352,655 & 161974,4 & $-157621,745$ \\
\hline & built-up areas & 123310 & 165637 & -42327 \\
\hline & $\sum$ & 785398,075 & 785398,11 & $-0,035$ \\
\hline \multirow[t]{7}{*}{575} & woodland & 105798,9 & 109682,2 & $-3883,3$ \\
\hline & meadows and pastures & 9979,992 & 79749,69 & $-69769,698$ \\
\hline & arable land & 572904,1 & 417436,3 & 155467,8 \\
\hline & hedgerows, windbreaks and parks & 2283,955 & 116178,5 & $-113894,545$ \\
\hline & vineyards & 41119,6 & 0 & 41119,6 \\
\hline & built-up areas & 53311,51 & 62426,38 & $-9114,87$ \\
\hline & $\sum$ & $\mathbf{7 8 5 3 9 8 , 0 5 7}$ & 785473,07 & $-75,013$ \\
\hline \multirow[t]{5}{*}{576} & woodland & 14095,54 & 14221,46 & $-125,92$ \\
\hline & arable land & 700100,2 & 709581,2 & -9481 \\
\hline & hedgerows, windbreaks and parks & 1444,507 & 1572,802 & $-128,295$ \\
\hline & built-up areas & 69758,21 & 60023,06 & 9735,15 \\
\hline & $\sum$ & $\mathbf{7 8 5 3 9 8 , 4 5 7}$ & 785398,522 & $-0,065$ \\
\hline \multirow[t]{7}{*}{573} & meadows and pastures & 21146,68 & 10109,36 & 11037,32 \\
\hline & arable land & 621696,1 & 630639,6 & $-8943,5$ \\
\hline & hedgerows, windbreaks and parks & 0 & 1571,404 & $-1571,404$ \\
\hline & orchards and gardens & 8233,189 & 0 & 8233,189 \\
\hline & vineyards & 0 & 15646,57 & $-15646,57$ \\
\hline & built-up areas & 134322,2 & 127431,1 & 6891,1 \\
\hline & $\sum$ & 785398,169 & 785398,034 & 0,135 \\
\hline \multirow[t]{2}{*}{77} & meadows and pastures & 0 & 8460,033 & $-8460,033$ \\
\hline & arable land & 311016,1 & 288605,2 & 22410,9 \\
\hline
\end{tabular}


Journal of Landscape Ecology (2018), Vol: 11 / No. 1.

\begin{tabular}{|c|c|c|c|c|}
\hline & hedgerows, windbreaks and parks & 0 & 20654,93 & $-20654,93$ \\
\hline & orchards and gardens & 123516,5 & 124041 & $-524,5$ \\
\hline & built-up areas & 350865,1 & 343636,8 & 7228,3 \\
\hline & $\sum$ & $\mathbf{7 8 5 3 9 7 , 7}$ & 785397,963 & $-0,263$ \\
\hline \multirow[t]{6}{*}{923} & meadows and pastures & 0 & 3200,654 & $-3200,654$ \\
\hline & arable land & 706568,5 & 700804,9 & 5763,6 \\
\hline & hedgerows, windbreaks and parks & 19675,8 & 26145,38 & $-6469,58$ \\
\hline & orchards and gardens & 12309,81 & 0 & 12309,81 \\
\hline & built-up areas & 46843,92 & 55247,24 & $-8403,32$ \\
\hline & $\sum$ & $\mathbf{7 8 5 3 9 8 , 0 3}$ & $\mathbf{7 8 5 3 9 8 , 1 7 4}$ & $-0,144$ \\
\hline \multirow[t]{6}{*}{316} & meadows and pastures & 6392,9 & 60826,37 & $-54433,47$ \\
\hline & arable land & 487805,5 & 479348,9 & 8456,6 \\
\hline & hedgerows, windbreaks and parks & 0 & 28278,83 & $-28278,83$ \\
\hline & orchards and gardens & 153968,8 & 84442,76 & 69526,04 \\
\hline & built-up areas & 137230,7 & 132501,2 & 4729,5 \\
\hline & $\Sigma$ & 785397,9 & 785398,06 & $-0,16$ \\
\hline \multirow[t]{5}{*}{254} & meadows and pastures & 0 & 3465,435 & $-3465,435$ \\
\hline & arable land & 626345,3 & 613748,5 & 12596,8 \\
\hline & hedgerows, windbreaks and parks & 0 & 9925,352 & $-9925,352$ \\
\hline & built-up areas & 159052,8 & 158259 & 793,8 \\
\hline & $\sum$ & $\mathbf{7 8 5 3 9 8 , 1}$ & 785398,287 & $-0,187$ \\
\hline \multirow[t]{7}{*}{315} & meadows and pastures & 0 & 36685,85 & $-36685,85$ \\
\hline & arable land & 669828,2 & 564397,6 & 105430,6 \\
\hline & hedgerows, windbreaks and parks & 19196,33 & 63955,9 & $-44759,57$ \\
\hline & orchards and gardens & 1190,424 & 0 & 1190,424 \\
\hline & water bodies & 8135,585 & 5004,11 & 3131,475 \\
\hline & built-up areas & 87047,7 & 115354,8 & $-28307,1$ \\
\hline & $\Sigma$ & 785398,239 & 785398,26 & $-0,021$ \\
\hline \multirow[t]{3}{*}{149} & woodland & 122882 & 128846,8 & $-5964,8$ \\
\hline & meadows and pastures & 86046,82 & 102014,6 & $-15967,78$ \\
\hline & arable land & 434669,6 & 415131,1 & 19538,5 \\
\hline
\end{tabular}


Poprach K., Opluštil L., Krause F., Machar I.: Land-use changes at nest sites of the Little Owl (Athene noctua) in the South-Moravian region of the Czech Republic

\begin{tabular}{|c|c|c|c|c|}
\hline & hedgerows, windbreaks and parks & 3618,978 & 5535,885 & $-1916,907$ \\
\hline & built-up areas & 138180,7 & 133869,8 & 4310,9 \\
\hline & $\sum$ & 785398,098 & 785398,185 & $-0,087$ \\
\hline \multirow[t]{6}{*}{249} & meadows and pastures & 778,1456 & 4928,67 & $-4150,5244$ \\
\hline & arable land & 574050,3 & 563514,7 & 10535,6 \\
\hline & hedgerows, windbreaks and parks & 50345,64 & 73655,95 & $-23310,31$ \\
\hline & vineyards & 6883,973 & 0 & 6883,973 \\
\hline & built-up areas & 153340,1 & 143299 & 10041,1 \\
\hline & $\sum$ & 785398,1586 & 785398,32 & $-0,1614$ \\
\hline \multirow[t]{7}{*}{142} & woodland & 78973,41 & 84437,87 & $-5464,46$ \\
\hline & meadows and pastures & 5201,198 & 47114,22 & $-41913,022$ \\
\hline & arable land & 483145 & 411600,1 & 71544,9 \\
\hline & hedgerows, windbreaks and parks & 12669,39 & 28374,57 & $-15705,18$ \\
\hline & orchards and gardens & 55028,06 & 14263,1 & 40764,96 \\
\hline & built-up areas & 150380,6 & 199608,3 & $-49227,7$ \\
\hline & $\sum$ & 785397,658 & 785398,16 & $-0,502$ \\
\hline \multirow[t]{5}{*}{4247} & meadows and pastures & 0 & 15979,62 & $-15979,62$ \\
\hline & arable land & 518631,9 & 483764 & 34867,9 \\
\hline & hedgerows, windbreaks and parks & 11721,22 & 15298,61 & $-3577,39$ \\
\hline & built-up areas & 255045 & 270356 & -15311 \\
\hline & $\sum$ & 785398,12 & 785398,23 & $-0,11$ \\
\hline \multirow[t]{5}{*}{161} & meadows and pastures & 0 & 15979,62 & $-15979,62$ \\
\hline & arable land & 519464,2 & 484380,1 & 35084,1 \\
\hline & hedgerows, windbreaks and parks & 11242,78 & 14858,49 & $-3615,71$ \\
\hline & built-up areas & 254691,2 & 270179,9 & $-15488,7$ \\
\hline & $\sum$ & 785398,18 & 785398,11 & 0,07 \\
\hline \multirow[t]{5}{*}{183} & woodland & 0 & 18217 & -18217 \\
\hline & meadows and pastures & 7881,945 & 20713,13 & $-12831,185$ \\
\hline & arable land & 548511,4 & 486187 & 62324,4 \\
\hline & hedgerows, windbreaks and parks & 0 & 1016,626 & $-1016,626$ \\
\hline & orchards and gardens & 51236,66 & 33968,34 & 17268,32 \\
\hline
\end{tabular}


Journal of Landscape Ecology (2018), Vol: 11 / No. 1.

\begin{tabular}{|c|c|c|c|c|}
\hline & built-up areas & 177768,1 & 225296,2 & $-47528,1$ \\
\hline & $\sum$ & 785398,105 & 785398,296 & $-0,191$ \\
\hline \multirow[t]{5}{*}{4214} & meadows and pastures & 12263,52 & 25962,12 & $-13698,6$ \\
\hline & arable land & 599458,5 & 567240,7 & 32217,8 \\
\hline & hedgerows, windbreaks and parks & 4287,967 & 6044,855 & $-1756,888$ \\
\hline & built-up areas & 169388,1 & 186150,5 & $-16762,4$ \\
\hline & $\Sigma$ & 785398,087 & $\mathbf{7 8 5 3 9 8 , 1 7 5}$ & $-0,088$ \\
\hline \multirow[t]{5}{*}{180} & meadows and pastures & 12210,05 & 24655,9 & $-12445,85$ \\
\hline & arable land & 602078,6 & 570846,7 & 31231,9 \\
\hline & hedgerows, windbreaks and parks & 4211,31 & 5972,716 & $-1761,406$ \\
\hline & built-up areas & 166898,2 & 183923 & $-17024,8$ \\
\hline & $\sum$ & 785398,16 & 785398,316 & $-0,156$ \\
\hline \multirow[t]{9}{*}{579} & woodland & 102145 & 128280,2 & $-26135,2$ \\
\hline & meadows and pastures & 49565,95 & 36543,71 & 13022,24 \\
\hline & arable land & 75641,37 & 57149,76 & 18491,61 \\
\hline & hedgerows, windbreaks and parks & 7599,428 & 11624,72 & $-4025,292$ \\
\hline & orchards and gardens & 33071,84 & 0 & 33071,84 \\
\hline & vineyards & 23512,05 & 21208,09 & 2303,96 \\
\hline & water bodies & 94999,63 & 97278,92 & $-2279,29$ \\
\hline & built-up areas & 398862,9 & 433312,8 & $-34449,9$ \\
\hline & $\sum$ & 785398,168 & 785398,2 & $-0,032$ \\
\hline \multirow[t]{8}{*}{577} & woodland & 223703,9 & 243431,5 & $-19727,6$ \\
\hline & meadows and pastures & 18355,77 & 15607,02 & 2748,75 \\
\hline & arable land & 367427,7 & 315214,9 & 52212,8 \\
\hline & hedgerows, windbreaks and parks & 2134,736 & 2661,987 & $-527,251$ \\
\hline & orchards and gardens & 62831,69 & 0 & 62831,69 \\
\hline & vineyards & 57389,85 & 134244 & $-76854,15$ \\
\hline & built-up areas & 53554,57 & 74239 & $-20684,43$ \\
\hline & $\sum$ & 785398,216 & $\mathbf{7 8 5 3 9 8 , 4 0 7}$ & $-0,191$ \\
\hline \multirow[t]{2}{*}{4284} & meadows and pastures & 3335,005 & 36305,07 & $-32970,065$ \\
\hline & arable land & 377241,7 & 402341 & $-25099,3$ \\
\hline
\end{tabular}


Poprach K., Opluštil L., Krause F., Machar I.: Land-use changes at nest sites of the Little Owl (Athene noctua) in the South-Moravian region of the Czech Republic

\begin{tabular}{|c|c|c|c|c|}
\hline & hedgerows, windbreaks and parks & 6297,001 & 15926,27 & $-9629,269$ \\
\hline & orchards and gardens & 69504,39 & 72133,93 & $-2629,54$ \\
\hline & vineyards & 95324,53 & 0 & 95324,53 \\
\hline & built-up areas & 233695,5 & 258692 & $-24996,5$ \\
\hline & $\sum$ & 785398,126 & 785398,27 & $-0,144$ \\
\hline \multirow[t]{6}{*}{205} & meadows and pastures & 0 & 24658,14 & $-24658,14$ \\
\hline & arable land & 540361 & 540801,7 & $-440,7$ \\
\hline & hedgerows, windbreaks and parks & 0 & 2379,115 & $-2379,115$ \\
\hline & orchards and gardens & 20070,2 & 10686,42 & 9383,78 \\
\hline & built-up areas & 224965,4 & 206877,2 & 18088,2 \\
\hline & $\sum$ & 785396,6 & 785402,575 & $-5,975$ \\
\hline \multirow[t]{5}{*}{157} & arable land & 402455,1 & 327147,3 & 75307,8 \\
\hline & hedgerows, windbreaks and parks & 7278,842 & 34587,78 & $-27308,938$ \\
\hline & orchards and gardens & 10424,32 & 0 & 10424,32 \\
\hline & built-up areas & 365239,8 & 423663 & $-58423,2$ \\
\hline & $\sum$ & 785398,062 & $\mathbf{7 8 5 3 9 8 , 0 8}$ & $-0,018$ \\
\hline \multirow[t]{5}{*}{251} & arable land & 538662,5 & 481642,2 & 57020,3 \\
\hline & hedgerows, windbreaks and parks & 11546,78 & 38223,47 & $-26676,69$ \\
\hline & orchards and gardens & 10424,32 & 0 & 10424,32 \\
\hline & built-up areas & 224764,5 & 265532,4 & $-40767,9$ \\
\hline & $\sum$ & 785398,1 & 785398,07 & 0,03 \\
\hline \multirow[t]{7}{*}{167} & meadows and pastures & 35241,22 & 34314,02 & 927,2 \\
\hline & arable land & 554925,6 & 478909,8 & 76015,8 \\
\hline & hedgerows, windbreaks and parks & 23241,32 & 19037,24 & 4204,08 \\
\hline & orchards and gardens & 6816,622 & 1897,017 & 4919,605 \\
\hline & water bodies & 4425,313 & 13442,67 & $-9017,357$ \\
\hline & built-up areas & 160748 & 237797,4 & $-77049,4$ \\
\hline & $\sum$ & 785398,075 & 785398,147 & $-0,072$ \\
\hline \multirow[t]{3}{*}{169} & meadows and pastures & 10306,31 & 4716,516 & 5589,794 \\
\hline & arable land & 658191,5 & 597700,9 & 60490,6 \\
\hline & hedgerows, windbreaks and parks & 0 & 2417,782 & $-2417,782$ \\
\hline
\end{tabular}


Journal of Landscape Ecology (2018), Vol: 11 / No. 1.

\begin{tabular}{|c|c|c|c|c|}
\hline & orchards and gardens & 6485,241 & 0 & 6485,241 \\
\hline & built-up areas & 110415,1 & 180563 & $-70147,9$ \\
\hline & $\sum$ & 785398,151 & $\mathbf{7 8 5 3 9 8 , 1 9 8}$ & $-0,047$ \\
\hline \multirow[t]{8}{*}{4217} & woodland & 39273 & 41798,48 & $-2525,48$ \\
\hline & meadows and pastures & 17557,39 & 0 & 17557,39 \\
\hline & arable land & 373818,8 & 443590,6 & $-69771,8$ \\
\hline & hedgerows, windbreaks and parks & 2284,629 & 4901,668 & $-2617,039$ \\
\hline & orchards and gardens & 99720,27 & 0 & 99720,27 \\
\hline & vineyards & 8199,142 & 0 & 8199,142 \\
\hline & built-up areas & 244544,1 & 295133,3 & $-50589,2$ \\
\hline & $\Sigma$ & 785397,331 & 785424,048 & $-26,717$ \\
\hline \multirow[t]{8}{*}{252} & woodland & 80151,2 & 89364,03 & $-9212,83$ \\
\hline & meadows and pastures & 23331,1 & 23885,84 & $-554,74$ \\
\hline & arable land & 297599,4 & 293904,3 & 3695,1 \\
\hline & hedgerows, windbreaks and parks & 5924,124 & 20685,11 & $-14760,986$ \\
\hline & orchards and gardens & 54145,29 & 0 & 54145,29 \\
\hline & vineyards & 266673,5 & 288272,7 & $-21599,2$ \\
\hline & built-up areas & 57572,97 & 69285,71 & $-11712,74$ \\
\hline & $\sum$ & $\mathbf{7 8 5 3 9 7 , 5 8 4}$ & 785397,69 & $-0,106$ \\
\hline \multirow[t]{6}{*}{215} & meadows and pastures & 3120,558 & 11285,18 & $-8164,622$ \\
\hline & arable land & 624526,7 & 590300 & 34226,7 \\
\hline & hedgerows, windbreaks and parks & 0 & 4400,489 & $-4400,489$ \\
\hline & orchards and gardens & 2157,589 & 0 & 2157,589 \\
\hline & built-up areas & 155593,3 & 179412,4 & $-23819,1$ \\
\hline & $\sum$ & 785398,147 & 785398,069 & 0,078 \\
\hline \multirow[t]{7}{*}{581} & woodland & 2879,407 & 6556,433 & $-3677,026$ \\
\hline & meadows and pastures & 27605,51 & 17186,4 & 10419,11 \\
\hline & arable land & 349180,5 & 384815,8 & $-35635,3$ \\
\hline & hedgerows, windbreaks and parks & 7976,901 & 41390,02 & $-33413,119$ \\
\hline & vineyards & 297890,8 & 194855,2 & 103035,6 \\
\hline & built-up areas & 99865,07 & 140594,1 & $-40729,03$ \\
\hline & $\sum$ & $\mathbf{7 8 5 3 9 8 , 1 8 8}$ & 785397,953 & 0,235 \\
\hline
\end{tabular}


Poprach K., Opluštil L., Krause F., Machar I.: Land-use changes at nest sites of the Little Owl (Athene noctua) in the South-Moravian region of the Czech Republic

\begin{tabular}{|l|l|l|l|l|} 
& & & & \\
\hline 580 & woodland & 0 & 6137,046 & $-6137,046$ \\
\hline & meadows and pastures & 7601,349 & 43187,85 & $-35586,501$ \\
\hline & arable land & 559958,3 & 307539,2 & 252419,1 \\
\hline & hedgerows, windbreaks and parks & 8967,741 & 20871,77 & $-11904,029$ \\
\hline & orchards and gardens & 52721,27 & 60109,34 & $-7388,07$ \\
\hline & vineyards & 106366,6 & 300491,7 & $-194125,1$ \\
\hline & built-up areas & 49782,84 & 47061,28 & 2721,56 \\
\hline & & $\mathbf{7 8 5 3 9 8 , 1}$ & $\mathbf{7 8 5 3 9 8 , 1 8 6}$ & $-0,086$ \\
\hline & & & & \\
\hline
\end{tabular}

Table 2: Land-use within $500 \mathrm{~m}$ from the nest sites of the Little Owl (Athene noctua) in the South-Moravian region, Czech Republic, in the years 1976/1977 and $2014(n=35)$

\begin{tabular}{|l|c|c|c|c|c|}
\hline \multirow{2}{*}{ Land-use type } & \multicolumn{2}{|c|}{$1976 / 1977$} & \multicolumn{2}{c|}{} & $\begin{array}{l}\text { Differences in land-use } \\
\text { between 1976/1977 and } \\
\text { a014 }\end{array}$ \\
\hline & $\mathbf{n}(\mathbf{m})$ & $\%$ & $\mathbf{n}(\mathbf{m 2})$ & $\%$ & $\%$ \\
\hline woodland & 829274,377 & $3,02 \%$ & 949609,599 & $3,45 \%$ & $0,44 \%$ \\
\hline $\begin{array}{l}\text { meadows and } \\
\text { pastures }\end{array}$ & 405007,509 & $1,47 \%$ & 816197,877 & $2,97 \%$ & $1,50 \%$ \\
\hline arable land & 18401002,3 & $66,94 \%$ & 17112758,06 & $62,25 \%$ & $-4,69 \%$ \\
\hline $\begin{array}{l}\text { hedgerows, } \\
\text { windbreaks and parks }\end{array}$ & 315125,998 & $1,15 \%$ & 727951,471 & $2,23 \%$ & $1,08 \%$ \\
\hline orchards and gardens & 1031127,63 & $3,75 \%$ & 483349,577 & $1,76 \%$ & $-1,99 \%$ \\
\hline vineyards & 907712,7 & $3,30 \%$ & 1116692,66 & $4,48 \%$ & $1,18 \%$ \\
\hline water bodies & 111414,235 & $0,41 \%$ & 121985,15 & $0,44 \%$ & $0,04 \%$ \\
\hline built-up areas & 5488266,75 & $19,97 \%$ & 6160496,79 & $22,41 \%$ & $2,45 \%$ \\
\hline Total & $\mathbf{2 7 4 8 8 9 3 1 , 5}$ & $\mathbf{1 0 0 , 0 0 \%}$ & $\mathbf{2 7 4 8 9 0 4 1 , 1 8}$ & $\mathbf{1 0 0 , 0 0 \%}$ & \\
\hline
\end{tabular}

